\title{
Research Article \\ Selection Criteria for Improving Yield in Chili (Capsicum annuum)
}

\author{
S. Chakrabarty and A. K. M. Aminul Islam \\ Department of Genetics and Plant Breeding, Bangabandhu Sheikh Mujibur Rahman Agricultural University, Gazipur 1706, Bangladesh \\ Correspondence should be addressed to A. K. M. Aminul Islam; aminuljkkp@yahoo.com
}

Received 12 March 2017; Revised 25 April 2017; Accepted 8 May 2017; Published 12 June 2017

Academic Editor: Harsh Raman

Copyright (C) 2017 S. Chakrabarty and A. K. M. Aminul Islam. This is an open access article distributed under the Creative Commons Attribution License, which permits unrestricted use, distribution, and reproduction in any medium, provided the original work is properly cited.

\begin{abstract}
The present investigation was carried out to estimate the genetic variability and character association. Significant differences were observed among the genotypes for all the 15 traits for 20 chili genotypes. The highest genotypic coefficient of variation and phenotypic coefficient of variation were found for ten edible fruit weight, number of fruits per plant, fruit yield per plant, ten dry fruit weight, fruit length, fruit width, and weight of seeds per fruit. High heritability coupled with very high genetic advance as per cent of mean was observed for ten edible fruit weight, ten dry fruit weight, fruit length, number of fruits per plant, and fruit yield per plant. Phenotypic correlation coefficient among different traits indicated that fruit yield per plant at green stage had significant and positive association with ten edible green fruit weight, number of primary branches, harvest duration, and first fruit maturity and significant negative correlation with days to first picking. The path coefficient analysis revealed that days to first picking had the maximum positive direct effect on fruit yield per plant followed by harvest duration, ten edible fruit weight, ten dry fruit weight, hundred-seed weight, number of fruits per plant, first fruit maturity, and number of primary branches. Days to first picking had the maximum positive direct effect but significant negative effect with fruit yield per plant which indicated that the trait should be selected to expunge the undesirable indirect effect in order to make use of the direct effect. Therefore, selection should be practiced for ten edible fruit weight, ten dry fruit weight, number of fruits per plant, harvest duration, and hundred-seed weight for direct improvement of fruit yield per plant.
\end{abstract}

\section{Introduction}

Chili $(2 n=24)$ belongs to the family Solanaceae that is grown all over the world. Chili has been used as part of the human diet as spice, condiments, and vegetables for its appealing color, flavor, and pungency since the advancement of civilization [1]. The cornucopia of nutritional and medicinal quality gives it extra importance in regular diet. India is the largest producer as well as exporter of chili followed by China. According to FAOSTAT, the production of dry chili in Bangladesh during 2012-2013 was 136788.27 ton which is very low compared to India (1238084.1 ton) and China (261934.2 ton). The major cause of low productivity of chili in Bangladesh is the lack of high yielding varieties or hybrids. The existing trend of low productivity of chili can be improved through developing high yielding varieties with desirable qualities. The prerequisite for improvement of a crop is the selection of variable genotype in respect of desired quantitative traits and its acquainted exploitation through efficient breeding methods $[2,3]$. The higher the variability present in a population, the higher chance for effective selection for desirable types [4]. Higher genetic variability with least environmental effect is considered in the selection of genotype but it is difficult when the traits are controlled by polygenes. In this case heritability coupled with genetic advance is the more useful measure for selecting the best individuals [5]. Adequate knowledge of the level of variability in the population, the degree of character association, and the relative importance of the yield components is the most important in selecting genotypes for an efficient breeding program. Correlation measures the strength of the association between two traits but correlation coefficients alone may not reveal the relative importance of the causal factors in relation to the dependent variable. 
TABLE 1: Analysis of variance (ANOVA) for 15 characters of chili.

\begin{tabular}{|c|c|c|c|}
\hline Traits & Replication (2) & Genotype (19) & Error (38) \\
\hline Days to first picking & 63.22 & $227.21^{* *}$ & 5.60 \\
\hline Harvest duration & 0.95 & $130.04^{* *}$ & 8.39 \\
\hline First fruit maturity & 1.52 & $137.91^{* *}$ & 4.41 \\
\hline $100 \%$ fruit maturity & 66.72 & $226.04^{* *}$ & 4.52 \\
\hline Plant height $(\mathrm{cm})$ & 95.24 & $597.09^{* *}$ & 61.66 \\
\hline Number of primary branches & 13.27 & $18.70^{* *}$ & 6.04 \\
\hline 10 edible fruit weight (g) & 76.39 & $20196.81^{* *}$ & 219.06 \\
\hline 10 dry fruit weight (g) & 1.48 & $109.04^{* *}$ & 0.38 \\
\hline Fruit length $(\mathrm{cm})$ & 0.07 & $59.28^{* *}$ & 0.84 \\
\hline Fruit width $(\mathrm{cm})$ & 0.02 & $0.55^{* *}$ & 0.01 \\
\hline Number of seeds per fruit & 202.82 & $884.11^{* *}$ & 24.33 \\
\hline Weight of seeds per fruit (g) & 0.01 & $0.03^{* *}$ & 0.00 \\
\hline Number of fruits per plant & 177.32 & $16041.42^{* *}$ & 243.35 \\
\hline 100-seed weight (g) & 0.01 & $0.04^{* *}$ & 0.00 \\
\hline Fruit yield per plant (g) & 370.31 & $155374.68^{* *}$ & 4218.06 \\
\hline
\end{tabular}

Values in parenthesis are degrees of freedom and $*$ and $* *$ indicate significance at $5 \%$ and $1 \%$ levels, respectively.

Thus path analysis [6] was done to partition the correlation coefficients into direct and indirect effects to identify the relative importance of yield contributing traits towards fruit yield per plant. Therefore, the present study was conducted to determine the extent of genetic variability for important yield attributes and to determine interrelationship among the traits and their direct and indirect effects on yield of chili.

\section{Materials and Methods}

The experiment was conducted at the field laboratory of the Department of Genetics and Plant Breeding, Bangabandhu Sheikh Mujibur Rahman Agricultural University, Gazipur, Bangladesh, during the Rabi season of 2015-2016. The experiment was laid out in a randomized block design with three replications. Twenty genotypes of chili collected from different countries such as Bangladesh, India, Japan, Thailand, Malaysia, Japan, China, and Australia were used as experimental materials and data were recorded on 15 quantitative traits. The observations were recorded on days to first picking, harvest duration, days to first fruit maturity, days to hundred per cent fruit maturity, plant height $(\mathrm{cm})$, number of primary branches, ten edible (green edible stage) fruit weight $(\mathrm{g})$, ten dry fruit weight (g), fruit (green edible stage) length $(\mathrm{cm})$, fruit (green edible stage) width $(\mathrm{cm})$, number of seeds per fruit, weight of seeds per fruit (g), number of fruits per plant, hundred-seed weight $(\mathrm{g})$, and fruit yield (green edible stage) per plant (g).

The analysis of variance was done by using computer software STAR (Statistical Tool for Agricultural Research). Genotypic and phenotypic coefficients of variations were estimated following the formulae used by Burton [7]. Heritability in broad sense was calculated by using the formulae suggested by Singh and Chaudhary [8]. The expected genetic advances for different characters under investigation were estimated according to the formulae used by Johnson et al. [5] and Allard [9]. Genetic advance expressed as percentage of mean was estimated by using the formulae as described by Comstock and Robinson [10]. Phenotypic correlations coefficients and path coefficient analysis were done by using statistical package software $\mathrm{R}$ version 3.1.2.

\section{Results and Discussion}

The mean performances of genotypes (Table 1) for different traits indicated that the high range of variability was recorded for fruits yield (green edible stage) per plant (97.82 g-804.57 g per plant) followed by ten edible fruit weight at green stage (9.70 g-272.93 g), number of fruits per plant (21.67-266.67), number of seeds per fruit (24.67-87.67), and plant height $(44.60 \mathrm{~cm}-93.72 \mathrm{~cm})$. Relatively low range of variability was observed in respect of weight of seeds per fruit $(0.15-0.53 \mathrm{~g})$, hundred-seed weight $(0.25 \mathrm{~g}-0.66 \mathrm{~g})$, fruit width at green stage $(0.70 \mathrm{~cm}-2.10 \mathrm{~cm})$, and number of primary branches (10.67-19.00) and these present investigation endorse the findings of Munshi et al. [11] and Arunkumar et al. [12]. The coefficient of variation (CV) in all the traits ranged from 1.18 to 21.51; slightly higher coefficient of variation (CV\%) was recorded in ten edible fruit weight at green stage followed by fruit yield per plant at green edible stage, number of primary branches, number fruits per plant, fruit length, and plant height (Table 2).

Analysis of variance (Table 1) revealed wide spectrum of variation among 20 genotypes for all the traits indicating the presence of sufficient genetic variability which can be exploited through selection. High amount of generic variability for many of these traits studies in chili has also corroborated the findings of Vani et al. [13], Farhad et al. [14], D. K. Singh and A. Singh, [15], and Krishnamurthy et al. [16]. The extent of variability present in the genotypes was measured in terms of range, general mean, coefficient of variation $(\% \mathrm{CV})$, genotypic coefficient of variation $(\mathrm{GCV})$, phenotypic coefficient of variation (PCV), broad sense heritability $\left(h_{b}{ }^{2}\right)$, genetic advance (GA), and genetic advance as $\%$ mean (Table 3 ). 


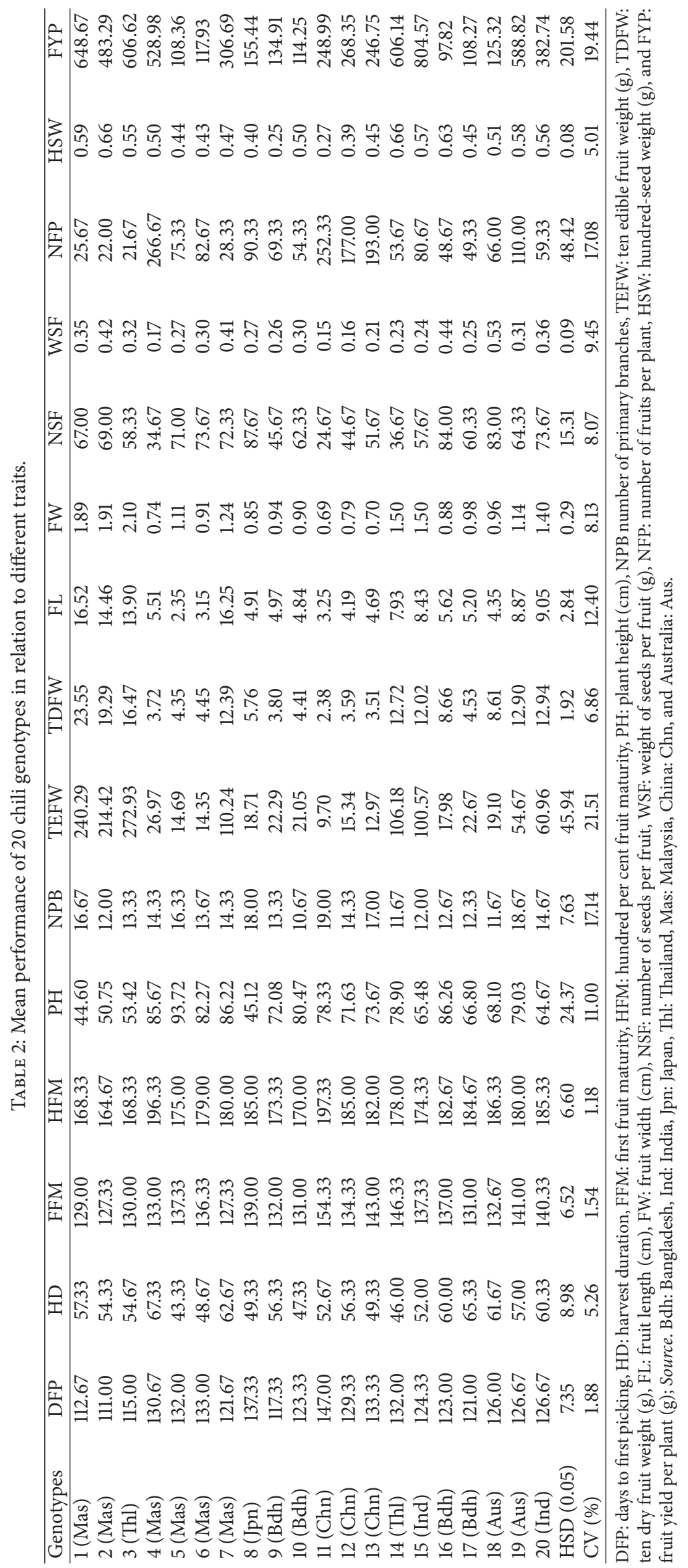




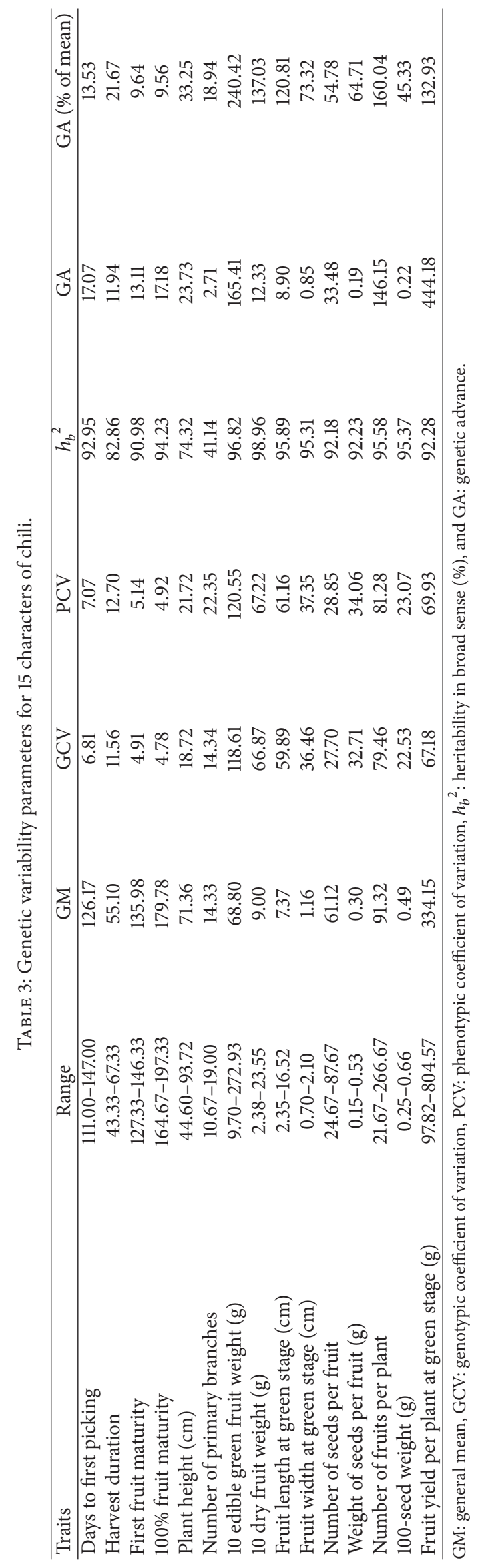


The phenotypic coefficient of variation (PCV) was higher than the genotypic coefficient of variation (GCV) for all the traits which was indicating the little influence of environment on the expression of these characters and considerable amount of variation was controlled by genetic makeup of the genotypes (Table 3). These findings are supported by earlier observations of Munshi et al. [11], Krishnamurthy et al. [16], and Sandeep et al. [17]. The estimates of GCV and PCV were high $(>30 \%)$ for ten edible fruit weight at green stage (118.61 and $120.55 \%)$, number of fruits per plant $(79.46$ and $81.28 \%$ ), fruit yield per plant at green stage (67.18 and $69.93 \%)$, ten dry fruit weight (66.87 and $67.22 \%)$, fruit length at green stage $(59.89$ and $61.16 \%)$, fruit width at green stage (36.46 and $37.35 \%)$, and weight of seeds per fruit (32.71 and $34.06 \%$ ) indicating the existence of wide range of genetic variability in the genotypes for these traits. This also indicates broad genetic base and less environmental influence and these traits are under the control of additive gene effects [18] ensuring opulent scope for further improvement of these traits through selection. These findings are in congruence with results of Farhad et al. [14], Tembhurne et al. [19], Rajyalakshmi, and Vijayapadma [20] for number of fruits per plant and Chattopadhyay et al. [21], Kumar et al. [2, 3], and Sandeep et al. [17] for fruit yield per plant.

Estimates of heritability along with genotypic coefficient variation are done to determine the amount of heritable portion of variation (Table 3 ). In the present study, very high broad sense heritability (90\% and above) was recorded for all the traits except harvest duration (82.86\%), plant height $(74.32 \%)$, and number of primary branches $(41.14 \%)$. Higher heritability was found for the traits of ten dry fruit weight (98.96\%), ten edible fruit weight (96.82\%), fruit length (95.89\%), number of fruits per plant (95.58\%), hundredseed weight (95.37\%), fruit width (95.31\%), hundred percent fruit maturity (94.23\%), days to first picking (92.95\%), fruit yield per plant $(92.28 \%)$, weight of seeds per fruit $(92.23 \%)$, number of seeds per fruit $(92.18 \%)$, and first fruit maturity (90.98\%). These findings are in compact with result of Das and Choudhary [22], Sreelathakumary and Rajamony [23], and Sharma et al. [24] for fruit yield per plant, Das and Choudhary [22] and Sharma et al. [24] for fruit weight, Sreelathakumary and Rajmony [23] and Sharma et al. [24] for number of fruits per plant, and Bharadwaj et al. [25] and Sharma et al. [24] for fruit length.

Johnson et al. [5] suggested that heritability estimates along with genetic advance is usually better than the heritability alone for selecting superior individuals. High heritability coupled with very high genetic advance as per cent of mean was observed for ten edible fruit weight, ten dry fruit weight, fruit length, number of fruits per plant, and fruit yield per plant which indicated that these traits were controlled by additive gene action and standard selection procedure could be effective for isolation of superior genotypes for these traits. These results are in accordance with results of earlier research of Chattopadhyay et al. [21], Kumar et al. [2, 3], and Sandeep et al. [17] for fruit yield per plant and Sreelathakumary and Rajamony, [23] for number of fruits per plant. High heritability coupled with moderate genetic advance as per cent of mean was observed for hundred-seed weight, fruit width, number of seeds per fruit, and weight of seeds per fruit indicating the preponderance of additive and nonadditive gene action and further improvement of these traits would be possible through mass selection, progeny selection, and hybridization procedure intending to exploit the additive gene action that was reported by Tembhurne et al. [19] and Suryakumari et al. [26]. Low heritability associated with low genetic advance as \% of mean was observed for harvest duration, plant height, and number of primary branches indicating the presence of nonadditive gene action for these traits and their improvement could be achieved through heterosis breeding.

The direction and magnificence of phenotypic association among different traits (Table 4) indicated that fruit yield per plant at green edible stage had significant and positive association with ten edible green fruit weight $\left(0.67^{* *}\right)$, number of primary branches $\left(0.06^{* *}\right)$, harvest duration $\left(0.05^{* *}\right)$, and first fruit maturity $\left(0.01^{* *}\right)$ and ten edible green fruit weight had highly significant and positive correlation with ten dry fruit weight $\left(0.88^{* *}\right)$, fruit length at green edible stage $\left(0.89^{* *}\right)$, fruit width at green edible stage $\left(0.93^{* *}\right)$, hundredseed weight $\left(0.51^{* *}\right)$, and weight of seeds per fruit $\left(0.27^{* *}\right)$ but negative correlation with days to first picking, first fruit maturity, hundred per cent fruit maturity, plant height, and number of fruits per plant. Similarly fruit length at green edible stage had highly significant and positive correlation with fruit width at green edible stage $\left(0.80^{* *}\right)$, hundred-seed weight $\left(0.50^{* *}\right)$, and weight of seeds per fruit $\left(0.38^{* *}\right)$. This association revealed that the selection for higher fruit yield per plant will be effective for isolating plants with higher ten edible green fruit weight followed by ten dry fruit weight, fruit length at green edible stage, fruit width at green edible stage, hundred-seed weight, and weight of seeds per fruit from the genotypes studied. Fruit yield per plant at green edible stage had also significant negative correlation with days to first picking $\left(-0.26^{* *}\right)$, hundred per cent fruit maturity $\left(-0.24^{* *}\right)$, plant height $\left(-0.29^{* *}\right)$, number of seeds per fruit $\left(-0.27^{* *}\right)$, and number of fruits per plant $\left(-0.02^{* *}\right)$.

Further path analyses were done to partition the correlation coefficients into direct and indirect effects to identify the relative importance of yield contributing traits towards fruit yield per plant of chili genotypes (Table 5). Direct and indirect effects of all the traits on fruit yield per plant were computed at the phenotypic level. The path coefficient analysis showed that days to first picking (2.71) had the maximum positive direct effect on fruit yield per plant followed by harvest duration (2.18) which was counter balanced by its negative indirect effect via hundred per cent fruit maturity $(-2.05)$, harvest duration $(-0.76)$, ten edible fruit weight $(-0.38)$, ten dry fruit weight $(-0.34)$, hundred-seed weight $(-0.15)$, and plant height $(-0.01)$. Direct selection for these types of traits could be practiced for the abatement of undesirable indirect effects. Other traits such as ten edible fruit weight, ten dry fruit weight, hundred-seed weight, number of fruits per plant, first fruit maturity, and number of primary branches had positive direct effect on yield. Positive indirect effect through ten dry fruit weight, fruit length, fruit width, hundred-seed weight, weight of seeds per fruit, number seeds per fruit, and harvest duration were responsible for significant positive correlation 


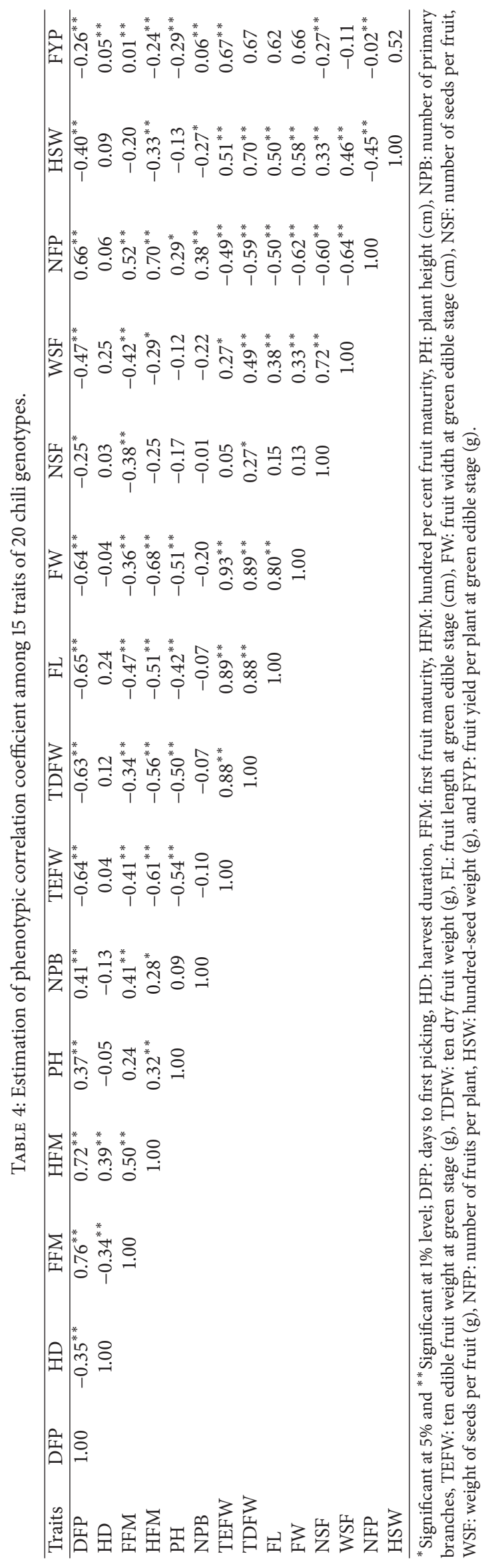




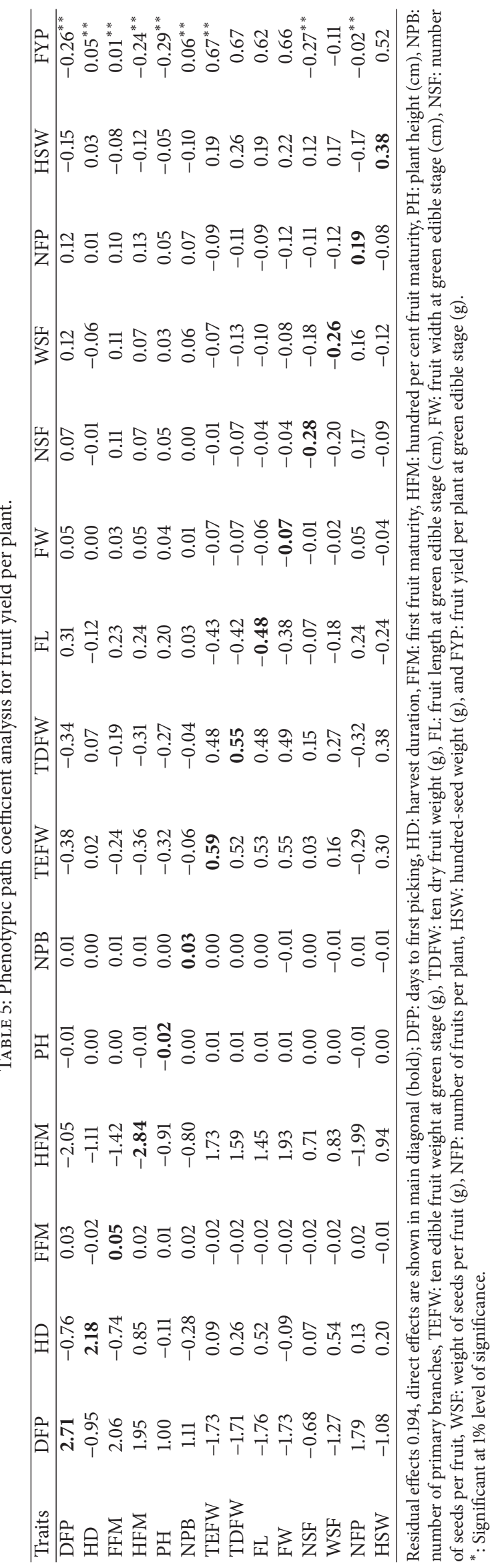


of ten edible fruit weight with fruit yield per plant. Highest negative direct effect was found for hundred per cent fruit maturity $(-2.84)$ followed by fruit length $(-0.48)$, number of seeds per fruit $(-0.28)$, weight seeds per fruit $(-0.26)$, fruit width $(-0.07)$, and plant height $(-0.02)$ and these traits also had positive contribution through indirect effect via other traits towards fruit yield per plant. Low residual effect (0.194) of path analysis indicated that maximum traits contributing to fruit yield per plant were considered in the present study.

\section{Conclusion}

The study indicated that sufficient genetic variability is present in the genotypes. Traits such as ten edible fruit weight at green stage, ten dry fruit weight, fruit length at green stage, and number of fruits per plant were highly heritable and controlled by additive gene action. Fruit yield per plant at green stage had significant and positive association with ten edible fruit weight at green stage, number of primary branches, harvest duration, and first fruit maturity. Path coefficient analysis revealed that days to first picking had the maximum positive direct effect on fruit yield per plant followed by harvest duration, ten edible fruit weight at green stage, ten dry fruit weight, hundred-seed weight, number of fruits per plant, first fruit maturity, and number of primary branches. Therefore, selecting genotypes for an efficient breeding program based on phenotypic indices such as ten edible fruit weight at green stage, ten dry fruit weight, number of fruits per plant, harvest duration, and hundred-seed weight would be rewarding.

\section{Conflicts of Interest}

The authors declare that there are no conflicts of interest regarding the publication of this paper.

\section{References}

[1] R. S. MacNeish, "Ancient mesoamerican civilization," Science, vol. 143, no. 3606, pp. 531-537, 1964.

[2] B. M. D. Kumar, K. Anand, and H. Mallikarjunasiah, "Genetic divergence in chilli accessions," Electronic Journal of Plant Breeding, vol. 1, no. 5, pp. 1363-1366, 2012.

[3] D. Kumar, V. Bahadur, S. B. Rangare, and D. Singh, "Genetic variability, heritability and correlation studies in chilli (Capsicum annuum L.).," Hort Flora Research Spectrum, vol. 1, pp. 248-252, 2012.

[4] N. I. Vavilov, "Origin, variation, immunity and breeding of cultivated plants," Chronology Botanya, vol. 13, pp. 4-364, 1951.

[5] H. E. Johnson, H. F. Robinson, and R. E. Comstock, "Estimates of genetic and environmental variability in soybean," Agronomy Journal, vol. 47, pp. 314-318, 1955.

[6] D. R. Dewey and H. K. Lu, "A correlation and path co-efficient analysis of component of crested wheat grass production," Agronomy Journal, vol. 51, pp. 515-518, 1959.

[7] G. M. Burton, "Quantitative inheritance in grasses," in Proceedings of 6th International Grassland Congress, vol. 1, pp. 277-283, Pennsylvania State College, 1952.
[8] R. K. Singh and B. D. Chaudhary, Biometrical Methods in Quantitative Genetic Analysis, p. 318, Kalyani publishers, New Delhi, India, 1985.

[9] R. W. Allard, Principles of Plant Breeding, p. 36, John willey and sons, New York, 1960.

[10] R. E. Comstock and H. F. Robinson, "Genetic parameters, their estimation and significance," in Proceedings of 6th International Congress, vol. 1, pp. 284-291, 1952.

[11] A. D. Munshi, B. K. Kumar, A. K. Sureja, and S. Joshi, "Genetic variability, heritability and genetic advance for growth, yield and quality traits in chilli," Indian Journal of Horticulture, vol. 67, pp. 114-116, 2010.

[12] B. Arunkumar, S. V. Sunilkumar, and S. I. Hanamashetti, "Genetic variability for phonological and biochemical characters in chilli (Capsicum annuum L.) genotypes," Bioinfolet, vol. 10, no. 2A, pp. 495-497, 2013.

[13] S. K. Vani, O. Sridevi, and P. M. Salimath, "Studies on genetic variability, correlation and path analysis in chilli (Capsicum annuum L.)," Annuals of Biology, vol. 23, pp. 117-121, 2007.

[14] M. Farhad, M. Hasanuzzaman, B. K. Biswas, A. K. Azad, and M. Arifuzzaman, "Reliability of yield contributing characters for improving yield potential in chilli (Capsicum annuum)," International Journal of Sustainable Crop Production, vol. 3, no. 3, pp. 30-38, 2008.

[15] D. K. Singh and A. Singh, "Assessment of variability parameters and character association for quantitative traits in chilli (Capsicum annuum L.)," Progressive Agriculture, vol. 11, no. 1, pp. 113116, 2011.

[16] S. L. Krishnamurthy, K. M. Reddy, and A. Mohan Rao, "Genetic variation, path and correlation analysis in crosses among Indian and Taiwan parents in chilli," Vegetable Science, vol. 40, no. 2, pp. 210-213, 2013.

[17] Sandeep, A. Somanath, and H. D. Mohan Kumar, "Genetic variability, heritability and genetic advance for yield and its components in Byadgi Kaddi chilli (Capsicum annuum L.) accessions," Bioinfolet, vol. 10, no. 1A, pp. 50-53, 2013.

[18] V. G. Panse, "Genetics of quantitative characters in relation to plant breeding," Indian Journal of Genetics, vol. 17, pp. 318-328, 1957.

[19] B. V. Tembhurne, R. Revanappa, and P. H. Kuchanur, "Varietal performance, genetic variability and correlation studies in chilli (Capsicum annuum L.)," Karnataka Journal of Agricultural Sciences, vol. 21, pp. 541-543, 2008.

[20] Rajyalakshmi and Vijayapadma, "Studies on performance, genetic variability, heritability and genetic advances in chilli (Capsicum annuum L.) varieties in high altitude and tribal zone of Srikakulam district of Andhra pradesh, India," Plant Archives, vol. 12, pp. 717-720, 2012.

[21] A. Chattopadhyay, B. S. Amit, N. Dai, and S. Dutta, "Diversity of genetic resources and genetic association analyses of green and dry chillies of eastern India," Chilean Journal of Agricultural Research, vol. 71, no. 3, pp. 350-356, 2011.

[22] S. Das and D. N. Choudhary, "Genetic variability in summer chilli (Capsicum annum L.)," Journal of Applied Biology, vol. 9, no. 1, pp. 8-10, 1999.

[23] I. Sreelathakumary and L. Rajamony, "Variability, heritability and correlation studies in chilli (Capsicum spp.) under shade," Indian Journal of Horticulture, vol. 59, no. 1, pp. 77-83, 2002.

[24] V. K. Sharma, C. S. Semwal, and S. P. Uniyal, "Genetic variability and character association analysis in bell pepper (Capsicum annuum L.)," Journal of Horticulture and Forestry, vol. 2, no. 3, pp. 58-65, 2010. 
[25] D. N. Bharadwaj, H. Singh, and R. K. Yadav, "Genetic variability and association of component characters for yield in chilli (Capsicum annum L.)," Progressive Agriculture, vol. 7, no. 1-2, pp. 72-74, 2007.

[26] S. Suryakumari, K. Uma Jyothi, D. Srihari, A. S. Sankar, and C. R. Sankar, "Variability and genetic divergence in paprika (Capsicum annuum L.)," Journal of Spices and Aromatic Crops, vol. 19, pp. 71-75, 2010. 


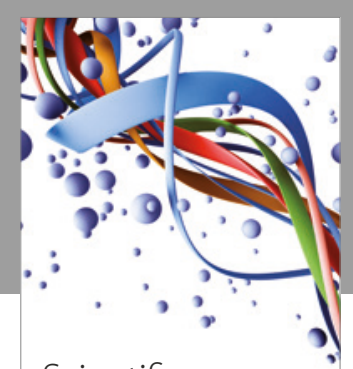

Scientifica
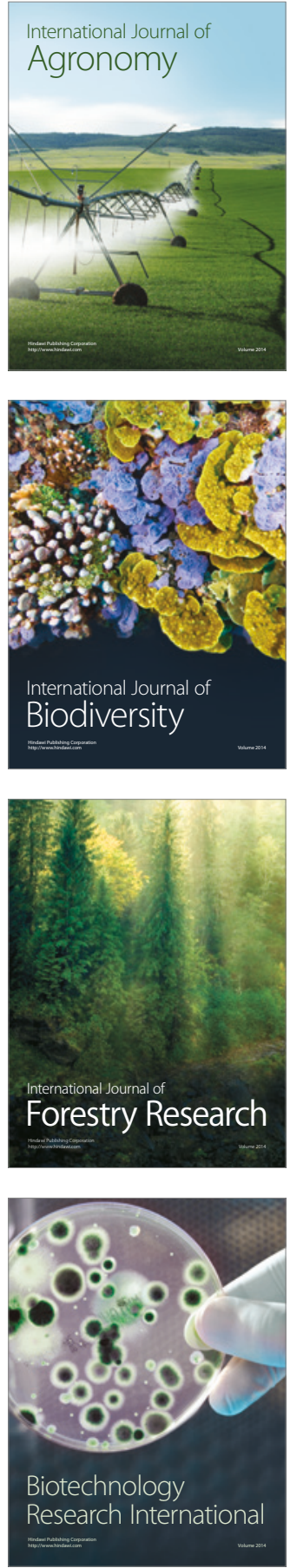
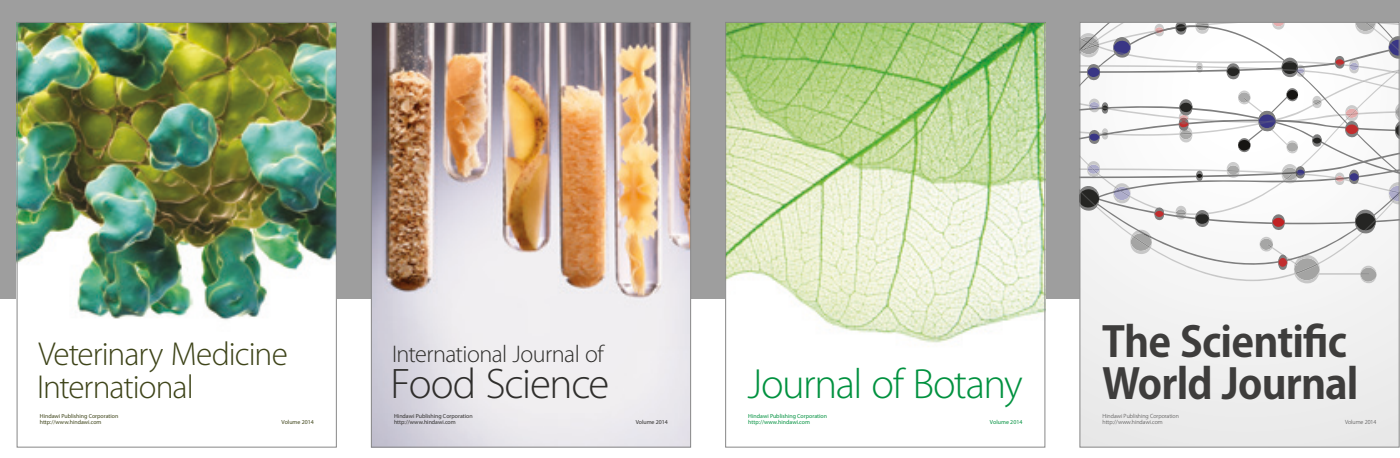

The Scientific

\section{World Journal}

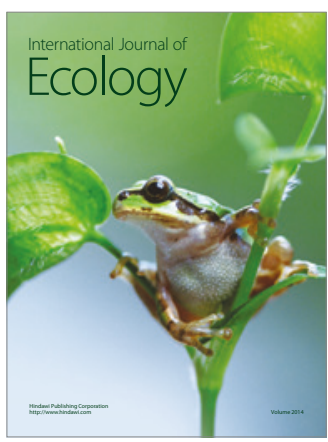

\section{Hindawi}

Submit your manuscripts at

https://www.hindawi.com
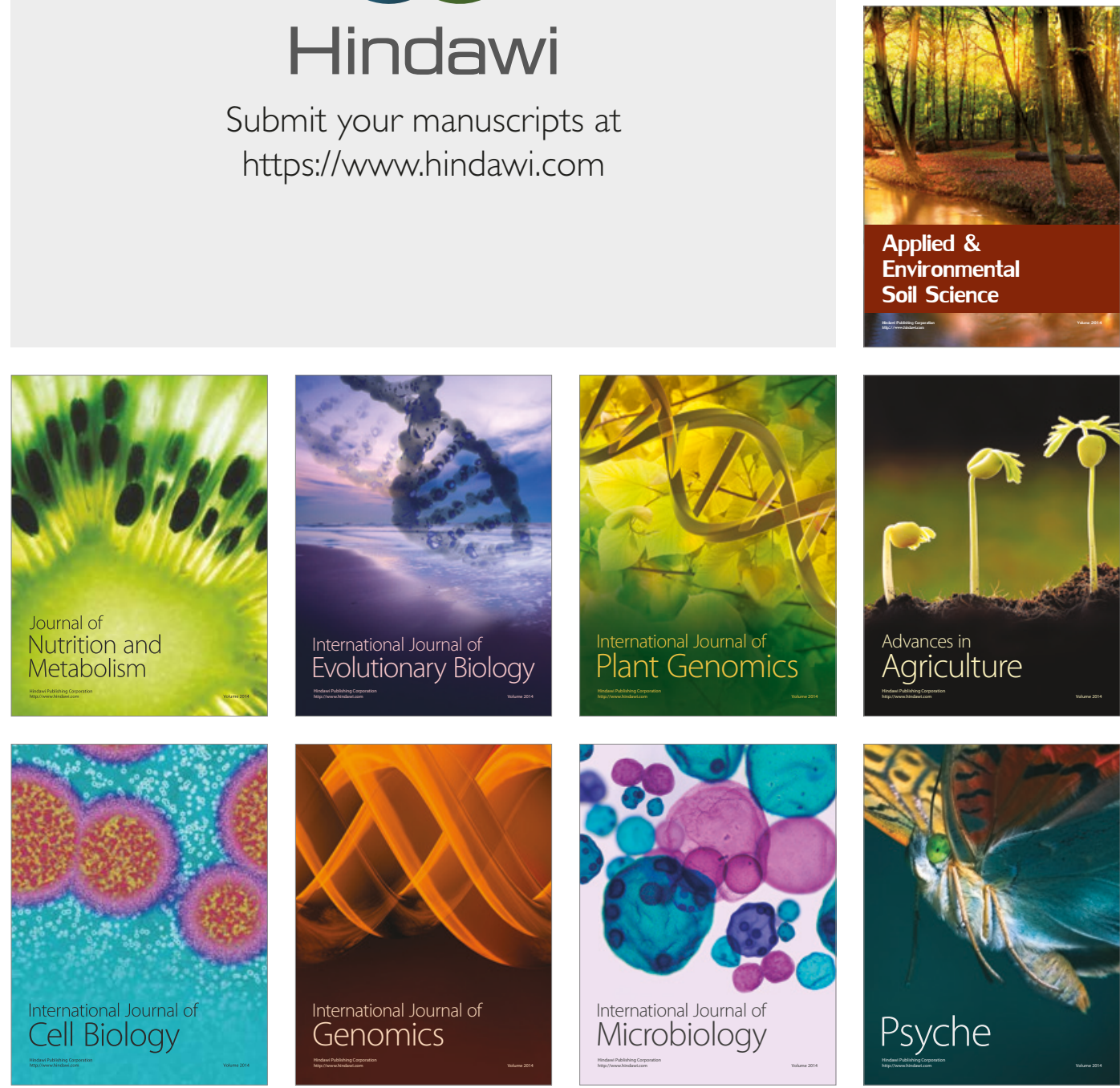

hternational Journal of Microbiology
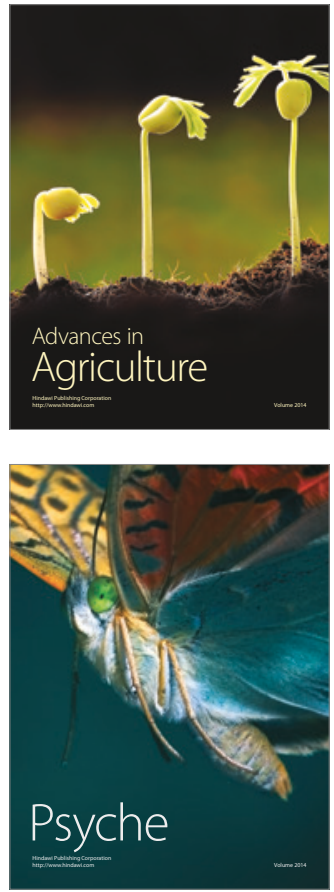